\title{
Jake Nabel. "Tiridates in the Forum, Peroz on his Knees: Religion and Reputation in ancient Iranian Diplomacy"
}

\section{Leonardo Gregoratti}

\section{(2) OpenEdition}

Journals

Electronic version

URL: https://journals.openedition.org/abstractairanica/53299

DOI: 10.4000/abstractairanica.53299

ISSN: 1961-960X

Publisher:

CNRS (UMR 7528 Mondes iraniens et indiens), Éditions de l'IFRI

\section{Electronic reference}

Leonardo Gregoratti, "Jake Nabel. "Tiridates in the Forum, Peroz on his Knees: Religion and Reputation in ancient Iranian Diplomacy"', Abstracta Iranica [Online], Volume 42-43 | 2021, document 50, Online since 30 December 2021, connection on 13 December 2022. URL: http://journals.openedition.org/ abstractairanica/53299; DOI: https://doi.org/10.4000/abstractairanica.53299

This text was automatically generated on 13 December 2022.

All rights reserved 


\title{
Jake Nabel. "Tiridates in the Forum, Peroz on his Knees: Religion and Reputation in ancient Iranian Diplomacy"
}

\author{
Leonardo Gregoratti
}

\section{REFERENCES}

Jake Nabel. "Tiridates in the Forum, Peroz on his Knees: Religion and Reputation in ancient Iranian Diplomacy", Anabasis 10, 2019, p, 214-236.

1 In this contribution, Nabel reflects on the meeting between king Tiridates and emperor Nero that took place in the Roman forum in $66 \mathrm{AD}$ and during which the Arsacid formally obtained by the Romans the kingship of Armenia. He establishes a parallel with a passage by Procopius where the Sasanian king Peroz, trapped with his army by the Hephthalites, is compelled to purchase salvation at the cost of his dignity. Peroz avoids humiliating himself in front of the enemy, simply performing the usual morning prayers prescribed by the Zoroastrian rite during the ceremony, letting the enemy perceive them as an act of submission. According to Nabel, Tiridates played a part with Nero in Rome shrewdly using protocols and languages from religious rituals meant to pay homage to deities and inducing the Romans to interpret his behaviours as a submission towards Nero. 


\section{AUTHORS}

\section{LEONARDO GREGORATTI}

Durham University 